\title{
木造建物の最大変位応答に対する地盤特性定数の変動の影響 INFLUENCE OF THE GROUND PROPERTY VARIATION TO THE MAXIMUM DISPLACEMENT RESPONSE OF JAPANESE WOODEN HOUSES
}

\author{
山田耕司*
}

Koji YAMADA

\begin{abstract}
The seismic breakdown probability of a building requires several parameters: the event probability of earthquakes, the variation of ground properties, and the seismic performance variation of a given building. In this paper, we discuss the influence of the ground property variation to the maximum displacement response of Japanese wooden houses. Monte Carlo simulation is employed to consider both the variation of ground properties and the seismic performance variation of a given building. As results, the variation coefficient of surface subsoil amplifying characteristic is $0.3-1.0$ under $5.0 \mathrm{~Hz}$. The variation coefficient of surface layer has a large effect on the estimate values of maximum displacement responses by the result of Monte Carlo simulation.
\end{abstract}

Keywords : Traditional timber wooden house, Ground Property, Monte Carlo simulation,

Maximum displacement response

軸組木造住宅,地盤特性, モンテカルロシミュレーション,最大変位応答

1. 序

本研究では, 個々の木造住宅に対する地震被害関数の創出を目的 として，地盤増幅特性の木造住宅の最大変位応答への影響を検討す る。これまでの地震被害関数は, 実地震災害の被害調查から統計的 に導き出されている。これは, 特定地域, 特定建物群に対する特定 地震動に対する関数であり, 個別の建物に対する被害関数ではない. 一方で, 社会的には, 建物の証券化が進み, 個別の建物の地震被害 リスクを検証する必要性が出てきている. 以上のことから, サイト 特性と建物の耐力特性を加味した地震被害関数作成手法の開発が急 務と考えられる.

そこで著者は, 既報 ${ }^{1)}$ において図 1 に示寸地震被害の発生メカニ ズムから, 建物の耐力特性の変動, および, 表層地盤の増幅特性の 変動, 基盤における地震動波形の非定常振動特性とその発生確率よ り，建物の被害確率をモンテカルロシミュレーションにより計算す る手順を図 2 のように提案した。この方法では， $\alpha_{\mathrm{i}}$ の発生確率を 持った基盤入力動（ $\left.\mathrm{E}_{\mathrm{i}}\right)$ に対して表層の地盤増幅の変動を考慮して 1 つの基盤入力動あたり $\mathrm{M}$ ケの入力地震動（ $\mathrm{W}_{\mathrm{j}}$ )を作成する. 次に この特定入力地震動 $\left(\mathrm{W}_{\mathrm{j}}\right)$ に対寸る, 対象建物の耐力の変動を考慮 した複数の地震応答解析を行い, その最大変位

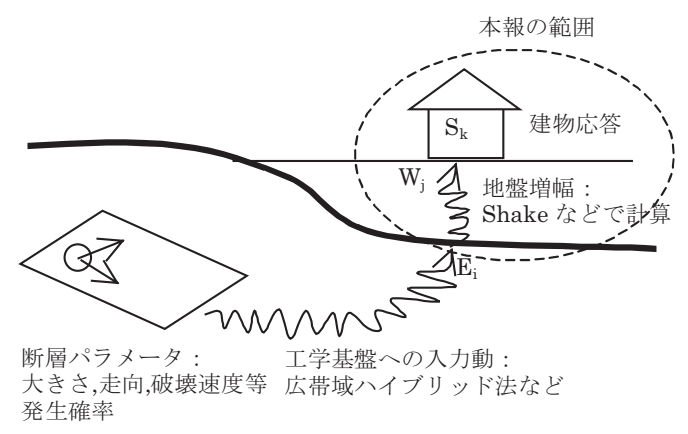

図 1 本報の研究範囲

応答の平均と分散に基づく地震被害関数（例えば正規分布を用い る）を作成し被害確率（ $\left.\beta_{\mathrm{j}}\right)$ を算定する. 従って, $\alpha_{\mathrm{i}}$ の発生確率 を持った基盤入力動（ $\left.\mathrm{E}_{\mathrm{i}}\right)$ に対する被害確率は， $\left(\Sigma \beta_{\mathrm{j}}\right) / \mathrm{M}$ で表さ れる. こうして求めた $\alpha_{\mathrm{i}}$ の発生確率を持った基盤入力動 $\left(\mathrm{E}_{\mathrm{i}}\right)$ に対 寸る被害確率の和により, 個別建物の被害確率 $\left(\sum \alpha_{\mathrm{i}}\left\{\left(\sum \beta_{\mathrm{j}}\right) / \mathrm{M}\right\}\right)$ を推定する.この場合, 解決すべき技術的問題は 3 つに集約される : 発生確率を伴った断層パラメータの設定, 地盤物性の変動を考慮し

\footnotetext{
* 豊田工業高等専門学校建築学科 准教授 ·博士 (工学)
}

Assoc. Prof., Dept. of Architecture, Toyota National College of Technology, Dr. Eng. 
た表層地盤増幅，耐力変動を考慮した建物応答，である．

以上の課題に対し，既報 ${ }^{1)}$ では，表 1 に示す地盤特性および而力 壁の変動組み合わせのうち, 耐力変動を考慮した建物被害確率の簡 易算定法を検討した。 その結果，剛床仮定の下， 1 建物に対して, 耐力壁の耐力の変動を考慮したモデル 20 例の最大変位応答を計算 寸れば，被害確率算定に用いても概衩妥当と判断した。そこで本報 では，サイトにおける地震動特性のうち“表層地盤における増幅特 性定数の変動”（3 節）, とモンテカルロシミュレーションを行う 際の表層地盤の必要モデル数（図 2 における $\mathrm{M} ， 5$ 節）を検討する. また，建物の耐力特性のうち“木造住宅における耐力壁の耐力特性 の変動” も考慮した場合の最大変位応答分布の変動を考察する $(6$ 節）.

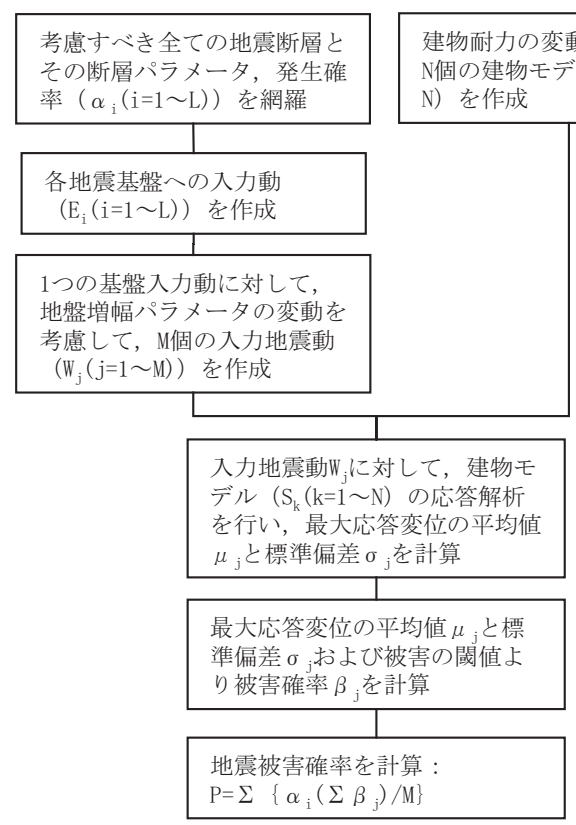

図 2 建物の地震被害確率の計算法

\begin{tabular}{|c|c|c|c|}
\hline & & \multicolumn{2}{|c|}{ 表層地盤の増幅特性 } \\
\hline & & 確定值 & 変動值 \\
\hline \multirow{2}{*}{$\begin{array}{c}\text { 耐力壁の耐 } \\
\text { 力特性 }\end{array}$} & 確定 & - & (0) (5 節) \\
\hline & 変動值 & $\bigcirc\left(\right.$ 既報 $\left.{ }^{1}\right), 4$ 節 $)$ & 一例 (6 節) \\
\hline
\end{tabular}

\section{2. 各種仮定・使用する既存建物の壁量}

\section{1 建物モデルの仮定}

本報では，既報 2),3)で用いた建物データを用いる．解析モデルは， 壁を耐震要素と考えた剛床仮定の疑似 3 次元モデルであり，耐震要 素の偏心が考慮されている，また，耐震要素として耐力壁，雑壁を 考慮し，その耐力特性に応じた等価せん断バネを仮定した．耐力壁 は二つ割筋かい，雑壁は石膏ボード雑壁を想定している，具体的な 解析事例を図 3 に示寸，図中の数字は，壁倍率を示している．最大 変位応答は, 変位の水平成分と回転成分から計算した剛床面内での 変位応答の最大值である，階高は， $2700 \mathrm{~mm}$ としている．建物質量 と回転慣性は表 2 に基づいて計算した。
耐力特性の変動を考慮する際は, 既報 ${ }^{1)}$ に基づき, 1 つの建物平 面プランに対して, 20 例の耐力壁・雑壁の最大耐力分布の異なる解 析モデルを作成した。 なお, 耐力特性の変動は, 耐力壁および雑壁 の最大耐力を正規分布で分布するとして, 壁長 $910 \mathrm{~mm}$ で設定した 各耐力壁・雑壁ごとに最大耐力を設定した. 図 4 に図 3 の建物にお ける壁耐力分布の 20 例中の 1 例を示寸. 図中の壁枚数は, 1 建物 内に配置される $910 \mathrm{~mm}$ 毎に区切られた壁枚数を表す.

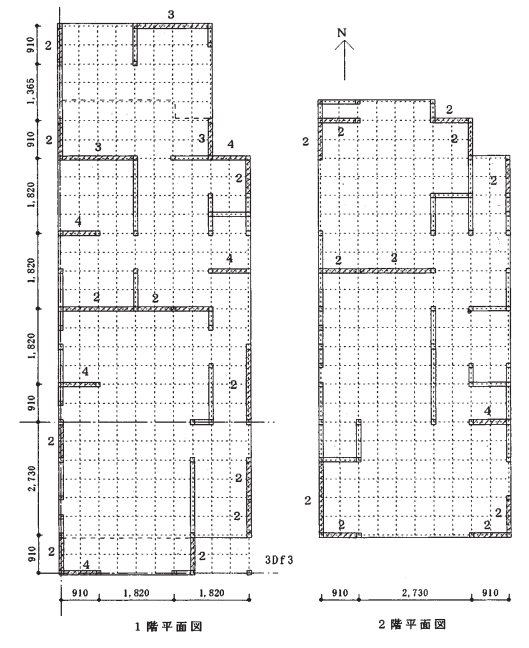

図 3 壁配置の具体的事例（4節の計算建物）

（2 階床レベル質量 $9500 \mathrm{~kg}$ ，小屋レベル質量 $6894 \mathrm{~kg}$ )

表 2 建物質量の仮定

\begin{tabular}{|l|l|l|}
\hline 項目 & 質量算定仮定* & 備考 \\
\hline 重い屋根 & $90 \mathrm{~kg} / \mathrm{m}^{2}$ & 施行令を参考（軒の深さは 0.75m) \\
\hline 軽い屋根 & $60 \mathrm{~kg} / \mathrm{m}^{2}$ & 施行令を参考（軒の深さは $0.75 \mathrm{~m}$ ) \\
\hline 外壁 & $190 \mathrm{~kg} / \mathrm{m}$ & サイディング+軸組+ボード内壁 \\
\hline 内壁 & $95 \mathrm{~kg} / \mathrm{m}$ & $\begin{array}{l}\text { ボード内壁+軸組+ボード内壁 } \\
\text { (雑壁長は壁実長の2 倍になる) }\end{array}$ \\
\hline 床 & $50 \mathrm{~kg} / \mathrm{m}^{2}$ & 施行令を参考 \\
\hline 積載物 & $60 \mathrm{~kg} / \mathrm{m}^{2}$ & 施行令を参考 \\
\hline
\end{tabular}

* : 外壁・内壁は壁長さ $1 \mathrm{~m}$ あたりの質量, その他は床面積 $1 \mathrm{~m}^{2}$ あた りの質量を表す

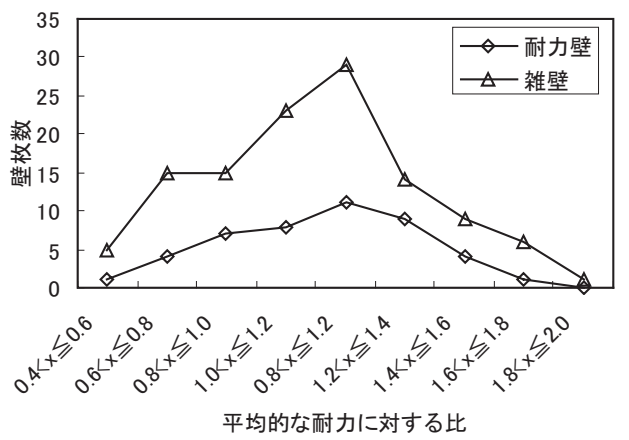

図 4 図 3 の建物における壁耐力分布の例（20 例中の 1 例） (図中の $\mathrm{x}$ は, 設定された最大耐力の最大耐力平均值に対する比)

耐力壁 1 枚毎に復元力特性の変動を与えるため, 次のルールで壁 長を分割した。壁実長 $910 \mathrm{~mm}$ 以上の耐力壁・雑壁は, $910 \mathrm{~mm}$ 程度 の壁が連続して設置されていると仮定し, 次のルールにより複数の 
壁に分割した．耐力壁は，壁実長 $1450 \mathrm{~mm}$ 以下を 1 枚の壁と考え， 壁実長 $1450 \mathrm{~mm}$ を超える場合は，910mm 毎に壁を分割した（例え ば，壁実長 $2300 \mathrm{~mm}=910 \mathrm{~mm}+1390 \mathrm{~mm}$ の 2 ケの壁とする）。実際は 壁実長 $1800 \mathrm{~mm}$ の耐力壁も存在したが，本報では壁実長 $910 \mathrm{~mm}$ を 標準と考える，雑壁は無開口壁のみを対象とし，垂壁，腰壁は雑壁 に算入しない。 また，雑壁は大壁形式，外周壁においては片面貼り， 内壁においては両面貼りと仮定した。雑壁も, 耐力壁の場合と同様 に，壁実長 $910 \mathrm{~mm}$ ごとに 1 つの雑壁としてまとめ, 端数 $(900 \mathrm{~mm}$ 未 満)も雑壁として算入した (例えば, 壁実長 $2300 \mathrm{~mm}=910 \mathrm{~mm}+910 \mathrm{~mm}$ +480mmの 3 ケの壁とする）.

減衰定数は，1 次固有周期に対して初期剛性比例 3\%と設定した。

\section{2 壁の骨格曲線と復元力特性}

図 5 に文献 4)に基づく壁 $1 \mathrm{~m}$ 当たりの骨格曲線，復元力特性を示 す.この履歴モデルは文献 3)の Bilinear 型バネと Slip 特性を持つ Tri-linear 型バネの並列バネであり，一方向の最大耐力を越える経 験最大変位を正負両方向の変位で共有している. また，除荷時は， 第 1 剛性で除荷されるものとしている.

本報では, 図 5 中の復元力特性を平均的な復元力特性として用い, 壁耐力の変動は所定の変動係数でばらつかせた最大耐力に比例する 形で，耐力方向に復元力特性を変化させる. 図 5 の設定パラメータ 一を表 3 に示す. 各耐力壁の変動は, 文献 5)を参考に, 最大耐力を 平均 $8 \mathrm{kN}$ 変動係数 0.3 として正規分布で設定最大耐力を生成してい る. 雑壁の耐力分布特性は不明であるが，耐力壁の変動を準用し， 変動係数を 0.3 とした。

なお，一般の木造軸組建物では， 1 階の最大層間変位が 2 階の最 大層間変位に卓越するため, 本報で論じる最大变位応答は 1 階のね じり振動も考慮した最大層間変位応答とする，数值積分には，中間 加速度法を用い，時間刻み 0.005 秒で計算している.

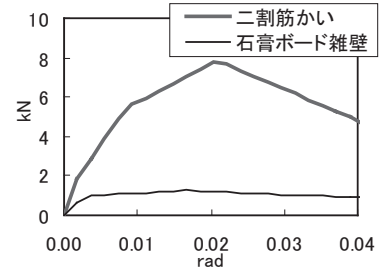

a) 壁 $1 \mathrm{~m}$ あたりの骨格曲線

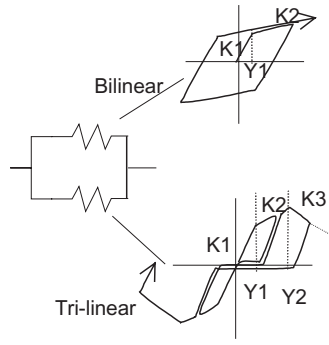

b) 復元力特性モデル 図 5 壁 $1 \mathrm{~m}$ あたりの骨格曲線および復元力特性

表 3 耐力壁と雑壁のパラメーター（壁長さ $1 \mathrm{~m}$ 当たりで表記）

\begin{tabular}{|c|c|c|c|c|c|c|}
\hline \multicolumn{2}{|c|}{} & \multicolumn{3}{|c|}{ 剛性 $(\mathrm{kN} / \mathrm{cm})$} & \multicolumn{2}{c|}{ 降伏変位 $(\mathrm{cm})$} \\
\cline { 2 - 7 } & $\mathrm{K} 1$ & $\mathrm{~K} 2$ & $\mathrm{~K} 3$ & $\mathrm{Y} 1$ & $\mathrm{Y} 2$ \\
\hline \multirow{2}{*}{$\begin{array}{c}\text { 耐 } \\
\text { 力 } \\
\text { 壁 }\end{array}$} & Bilinear & 2.39 & 0.13 & & 0.38 & \\
\cline { 2 - 8 } & Tri-1inear & 1.96 & 0.61 & -0.74 & 2.25 & 5.63 \\
\hline $\begin{array}{c}\text { 杂隹 } \\
\text { 壁 }\end{array}$ & Bilinear & 1.08 & 0.04 & & 0.23 & \\
\cline { 2 - 8 } & Tri-1inear & 0.81 & 0.04 & -0.07 & 0.90 & 4.50 \\
\hline
\end{tabular}

\section{3 使用する既存建物の充足率}

本建物群は既報 7)で用いた 2 階建て在来軸組構法木造住宅の内の 208 棟である. 本報では，X,Y 両方向を個別に計算する．従って，
計算サンプル数は 416 となる. 本報で使用した建物充足率（=耐力 壁量/表 4 の所用有効壁量）の分布，耐力壁の壁量より算定した 1 階 偏心率の分布を図 6 に示寸。 1 階充足率の平均は $1.67,2$ 階充足率 の平均 1.90, 1 階偏心率の平均は 0.16 である。また, 図より，1 階 充足率より 2 階充足率が高いこと， 1 階偏心率と 1 階充足率に相関 が低いことが分かる．以下，1階充足率のことを充足率と呼ぶ.

表 4 所用有効壁長 $(\mathrm{m})^{6)}$

\begin{tabular}{|l|c|c|}
\hline & 1 階 & 2 階 \\
\hline 軽い屋根 & $0.11 \mathrm{~A}_{1}+0.18 \mathrm{~A}_{2}$ & $0.15 \mathrm{~A}_{2}$ \\
\hline 重い屋根 & $0.15 \mathrm{~A}_{1}+0.18 \mathrm{~A}_{2}$ & $0.21 \mathrm{~A}_{2}$ \\
\hline
\end{tabular}

$\mathrm{A}_{1}, \mathrm{~A}_{2}$ : それぞれ 1 階, 2 階の床面積 $\left(\mathrm{m}^{2}\right)$
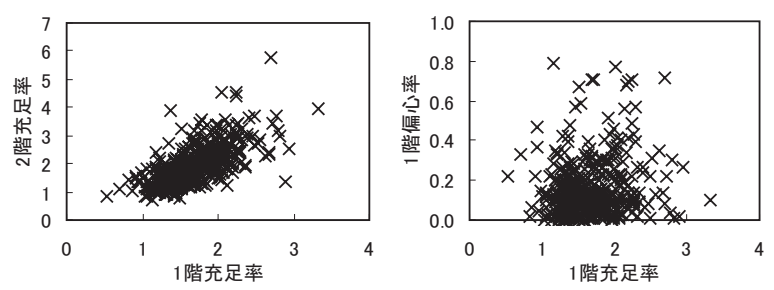

a) 充足率の分布

b) 1 階充足率と偏心率の関係 図 6 使用した建物の充足率と偏心率の分布

\section{3. 入力地震動}

\section{1 表層地盤の設定}

地盤モデルは，大崎ら ${ }^{8)}$ が我が国都市地域の地盤を類型化して作 成した沖積層 6 種（N值で記載，表 5 参照）を使用する。 N值と Vs の関係は, 今井 ${ }^{9)}$ 示した次式を用いる.

粘性土： $\mathrm{Vs}=102 \mathrm{~N}^{0.292}$

砂質土 : $\mathrm{Vs}=80.6 \mathrm{~N}^{0.331}$

結果として，表 5 のせん断波速度 $\mathrm{Vs}(\mathrm{m} / \mathrm{s})$ を基本值として用いる.

せん断波速度の変動は, 文献 10)を参考に Vs の変動係数 0.3 とし, Vs の分布関数は正規分布を仮定した。その上で，各々の表層地盤 種別毎に 100 ケの地盤データを作成した.

表 5 表層地盤の設定

\begin{tabular}{|c|c|c|c|c|}
\hline 沖積層種別 ${ }^{8)}$ & 層厚(m) & 土質 & N值 & 換算 $\mathrm{Vs}(\mathrm{m} / \mathrm{s})$ \\
\hline \multirow[t]{2}{*}{$\mathrm{A} 1$} & 7.0 & 砂質土 & 10 & 172.7 \\
\hline & 基盤 & & 40 & \\
\hline \multirow[t]{2}{*}{$\mathrm{A} 2$} & 9.5 & 粘性土 & 2 & 124.9 \\
\hline & 基盤 & & 40 & \\
\hline \multirow[t]{3}{*}{ A3 } & 5.5 & 砂質土 & 12 & 183.5 \\
\hline & 11.0 & 粘性土 & 2 & 124.9 \\
\hline & 基盤 & & 45 & \\
\hline \multirow[t]{4}{*}{$\mathrm{A} 4$} & 4.5 & 砂質土 & 12 & 183.5 \\
\hline & 10.0 & 粘性土 & 2 & 124.9 \\
\hline & 6.5 & 砂質士 & 6.5 & 149.8 \\
\hline & 基盤 & & 50 & \\
\hline \multirow[t]{4}{*}{ A5 } & 8.5 & 粘性土 & 2 & 124.9 \\
\hline & 7.5 & 砂質土 & 20 & 217.3 \\
\hline & 6.0 & 粘性土 & 10 & 199.8 \\
\hline & 基盤 & & 45 & \\
\hline \multirow[t]{5}{*}{ A6 } & 5.5 & 砂 & 12 & 183.5 \\
\hline & 10.0 & 粘性土 & 2 & 124.9 \\
\hline & 4.5 & 砂 & 25 & 233.9 \\
\hline & 6.0 & 粘性土 & 10 & 199.8 \\
\hline & 基盤 & & 50 & \\
\hline
\end{tabular}




\section{2 地盤増幅計算時の設定}

地盤増幅特性の計算には，吉田の $\mathrm{DYNEQ}^{11)}$ を用いる。材料特性 は旧・建築基準法告示 1457 号とし，等価線形化法（SHAKE）で計 算している. 単位体積重量は, 表層地盤で $1.7 \mathrm{t} / \mathrm{m}^{3}$, 基盤で $2.0 \mathrm{t} / \mathrm{m}^{3}$ としている. Cut-off 振動数は $10 \mathrm{~Hz}$ としている.

工学基盤への入力動は，本来地震断層を想定すべきであるが，本 報では，表層地盤特性の最大変位応答への影響を考察するため，応 答スペクトルの安定した $80 \%$ に低減した BCJ-L2 波を解放基盤入力 として設定した，なお，地震動レベルの最大変位応答への影響を検 討するため，沖積層種別 A5 に関してのみ，40\%に低減した BCJ-L2 波（レベル 1 地震動を想定），120\%に増加させた BCJ-L2 波（過大 入力を想定）を入力し表層での入力地震動を作製した.

\section{3 地盤増幅特性}

地盤増幅特性（特性図中の太線は表 5 の換算 Vs より計算，細線 は変動を考慮した 100 事例中の 10 事例）および（5, 10, 20, 50, 100 波形に対する）振動数毎の変動係数を図 7 に示す．振動数毎の変動 係数は, 変動を考慮して作成した 100 ヶの地震動より計算している. 図中の太線は，表 5 の換算 Vs より計算した増幅特性である. 層数 が少ないほど卓越振動数が大きく変動することが分かる。しかし， 振動数毎の变動係数は層数が多いほど大きくなる傾向を示している。 また，全ての表層地盤において， $2 \mathrm{~Hz} \sim 4 \mathrm{~Hz}$ 間で振動数に比例して 変動係数が増大していることが分かる.

\section{4. 壁耐力の変動を考慮した場合の最大変位応答の変動}

建物の壁耐力変動の最大変位応答への影響を検討するため, 図 7 中の太線の増幅特性（変動を考慮しない場合の増幅特性）を考慮し た地震動で最大変位応答を計算した. 1 棟の壁配置に対して 100 事 例計算した最大変位応答の変動係数を図 8 に示す．地震動により多 少の変動はあるものの, 変動係数は 0.3 以下となっている.また, 建物の壁量充足率にほぼ無関係であることも分かる，これは，既報 12)の結果とも同じ傾向である.

\section{5. 地盤増幅特性の変動の影響とサンプル数の検討}

\section{1 地盤増幅特性の変動と最大変位応答の変動係数の関係}

地盤増幅特性変動の最大変位応答への影響を検討するため, 壁の 耐力特性を確定值（図 5, 表 3 の特性）として, 図 7 の地盤増幅特 性を持つ地震動 100 ケに対する応答計算を行った. 地震動 100 ケ に対する最大変位応答の変動係数を図 9 に示す. 基盤入力動の大き さの影響を見るために, 沖積層 A5 のみ基盤入力動（80\%に低減し た BCJ-L2 波）の大きさを $50 \%, 150 \%$ に変化させた場合を計算した． 図より, 層厚が薄く層数が少ない沖積層 $\mathrm{A} 1, \mathrm{~A} 2$ の場合は, 最大変位 応答の変動係数が 0.3 以下程度であり, 壁耐力の変動を検討した場 合と同程度の最大変位応答の変動が予測される。一方, 層厚が厚く 層数が増えた他の場合には, 最大変位応答の変動係数が 0.5 を超え る場合が多くなる．特に沖積層 A3 の場合には変動係数が 1.0 近傍 の場合が生じている．また，沖積層 A5 では，基盤入力動の増加に 伴い変動係数が大きくなる傾向がある. 結果として, 最大変位応答 と変動係数の関係は, 表層地盤, 基盤入力動の大きさにより異なり, 一定の傾向はないと言える
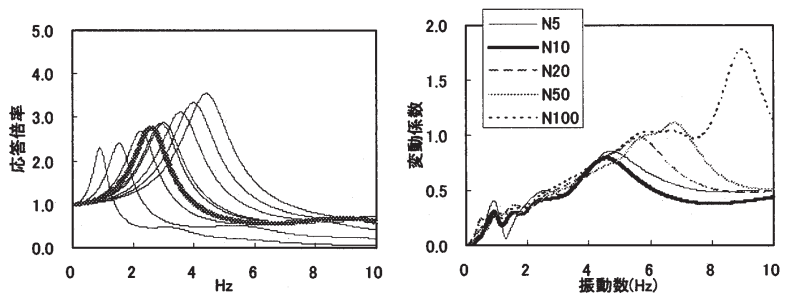

沖積層 $\mathrm{A} 1$
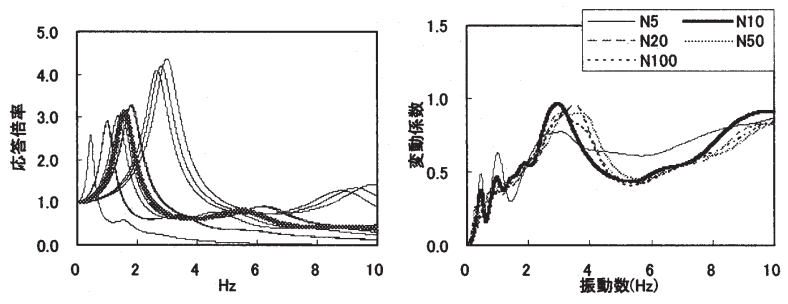

沖積層 $\mathrm{A} 2$
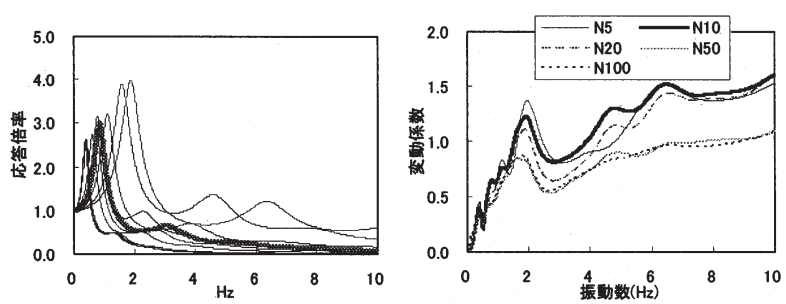

沖積層 A3
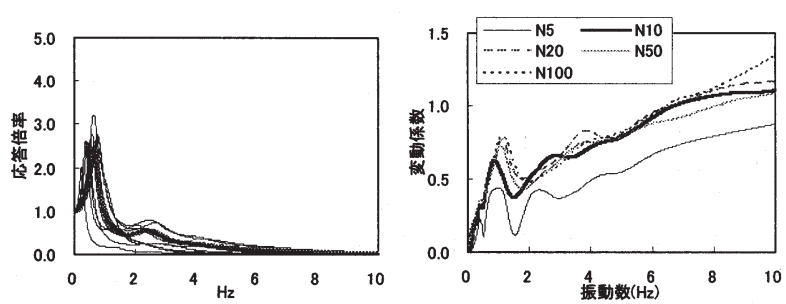

沖積層 $\mathrm{A} 4$
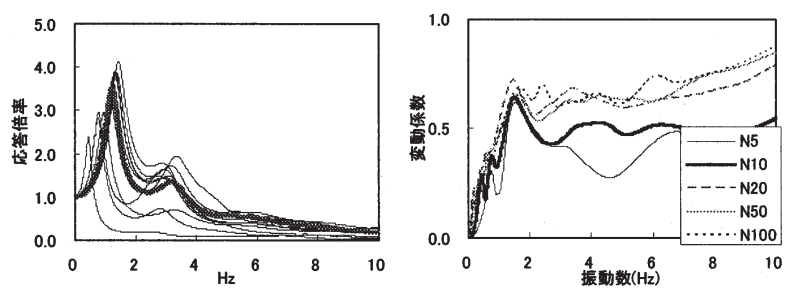

沖積層 A5
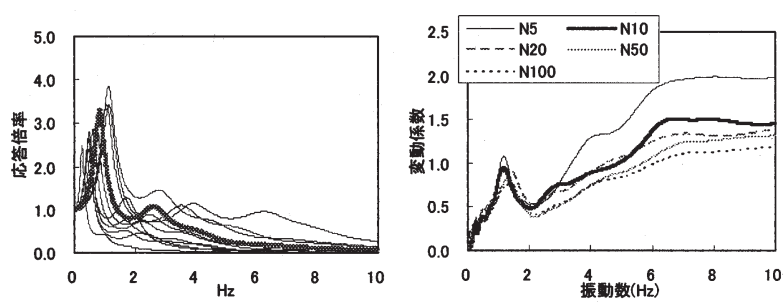

沖積層 A6

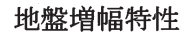

変動係数

図 7 地盤増幅特性および変動係数

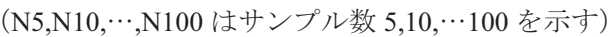




\section{2 地盤増幅特性のサンプル数の検討}

本節では，検討すべき地盤増幅特性のサンプル数を検討する. 先ず，図 3 建物の最大変位応答分布への地盤増幅特性サンプル数の 影響を検討する. 図 10 に地盤増幅特性サンプル数の図 3 建物の最

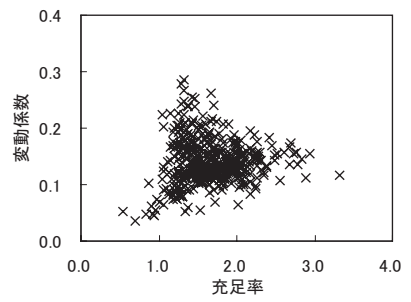

沖積層 A1

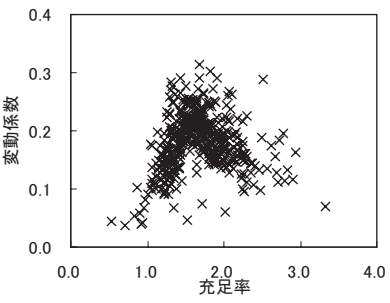

沖積層 A2

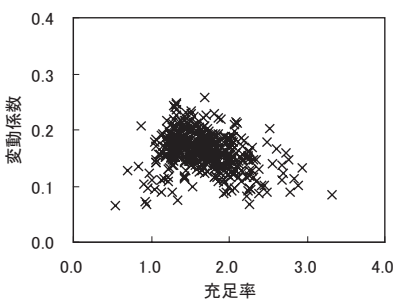

沖積層 A5

図 8 建物耐力の変動に起因寸るの最大変位応答の変動係数

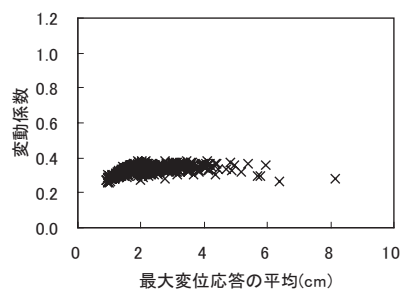

沖積層 $\mathrm{A} 1$

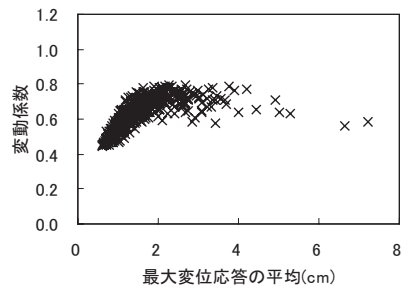

沖積層 A5

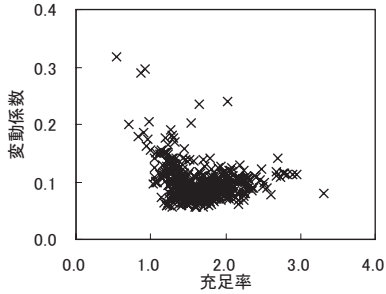

沖積層 $\mathrm{A} 3$

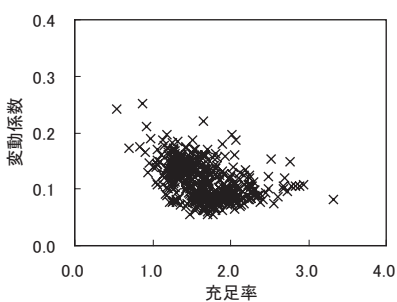

沖積層 A6

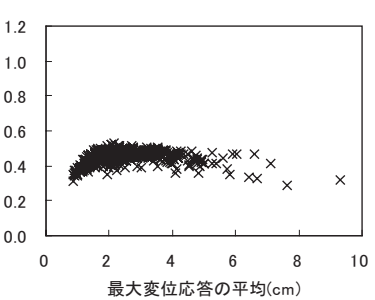

沖積層 A3

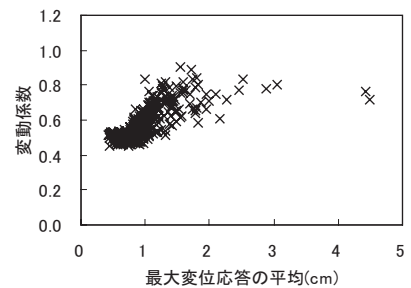

沖積層 A6
大変位応答分布への影響を示す. 100 事例の最大変位応答分布を正 解として比べると，40 事例以上の最大変位応答分布は，ほぼ同程 度の分布を示すことが分かる. 従って, 図 3 の建物では, 地盤増幅 特性サンプル数を 40 事例もしくは 50 事例にすれば効率的と言える。

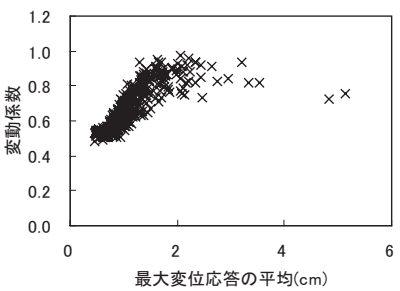

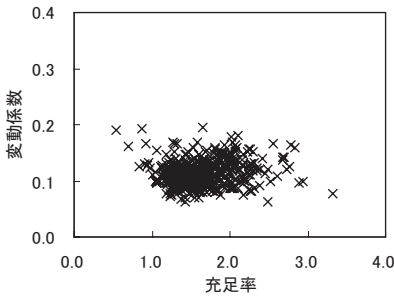

沖積層 A4

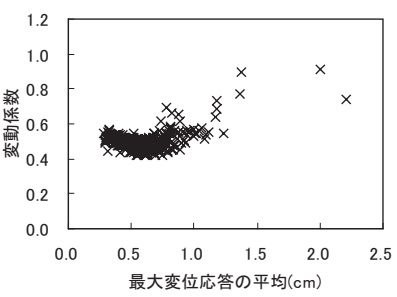

沖積層 A4
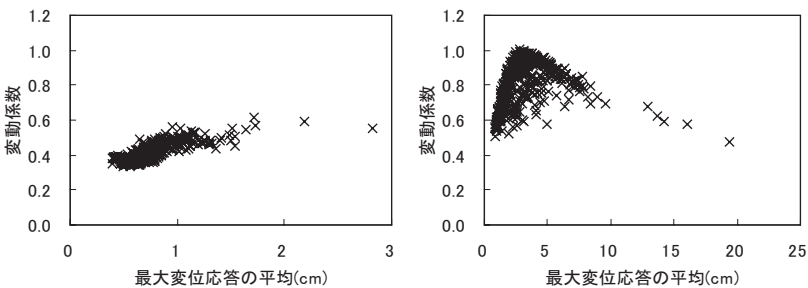

沖積層 A5（基盤入力 $50 \%$ ） 沖積層 A5（基盤入力 $150 \%$ ）

図 9 地盤増幅特性の最大変位応答への影響

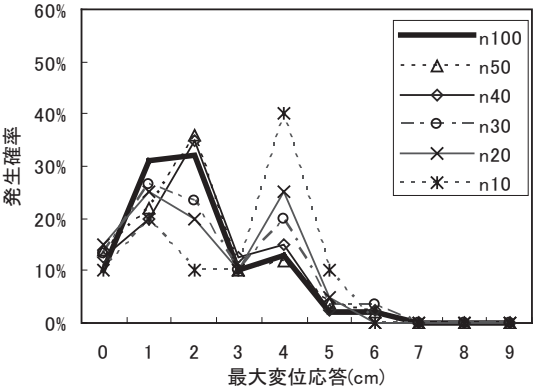

EW 方向

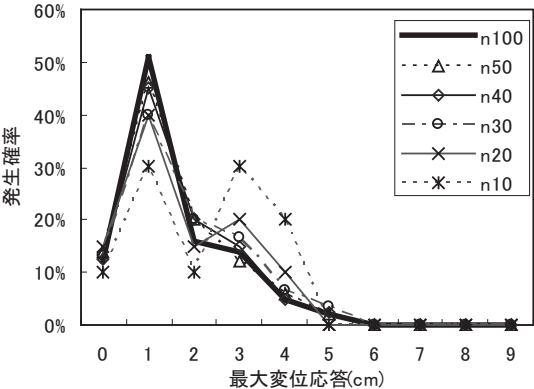

NS 方向

図 10 地盤増幅特性サンプル数の最大変位応答分布への影響

(図 3 の建物, 沖積層 A5, サンプル数 100,50,40,30,20,10 の場合) 
次に 416 ケの建物の最大変位応答の平均值 - 変動係数の地盤増幅 特性サンプル数を変更した場合の変化を検討する．平均值比を地盤 増幅特性サンプル数 100 事例の平均值に対するサンプル数 40 もし くは 50 事例の平均值の比, 変動係数比を同じく地盤増幅特性サン プル数 100 事例の変動係数に対する比と定義する. 図 11, 12 に地 盤増幅特性サンプル数の最大変位応答の平均值比・変動係数比への 影響を示す. 沖積層事例として, 図 10 で用いた A5 と比較的サン プル数の影響が大きかった A2 を示す. 沖積層 A2 の場合では, サ ンプル数 40 の平均值比, 変動係数比の分布は, サンプル数 50 の場 合に比して多少大きい. しかし, 図上で判断できるほど明確ではな い.
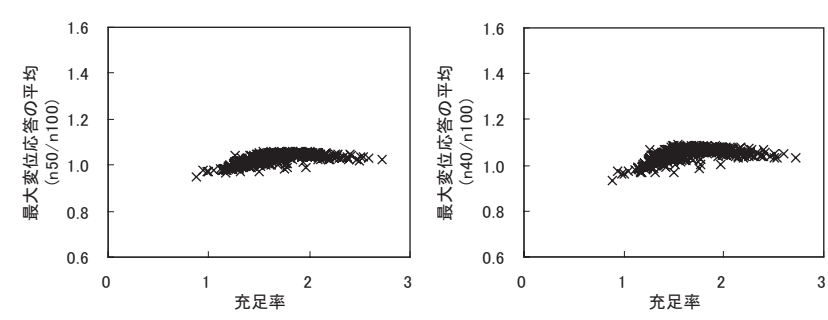

沖積層 $\mathrm{A} 2$
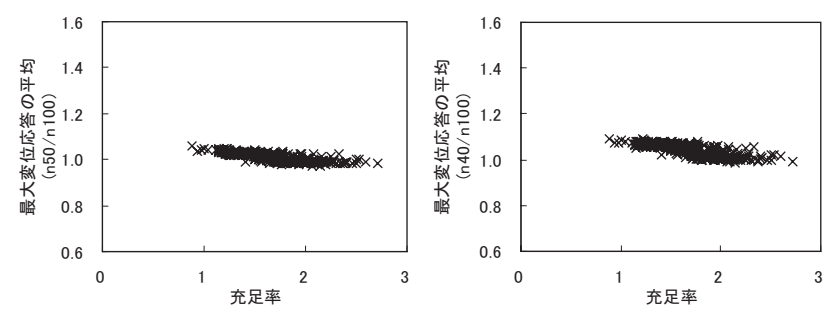

沖積層 A5

50 事例/100 事例 $\quad 40$ 事例/100 事例

図 11 地盤増幅特性サンプル数の平均值比への影響
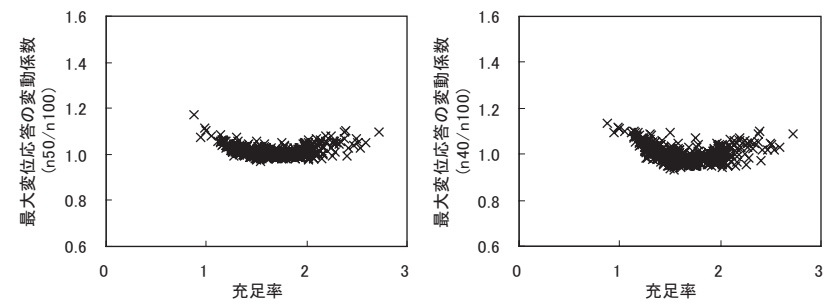

沖積層 A2
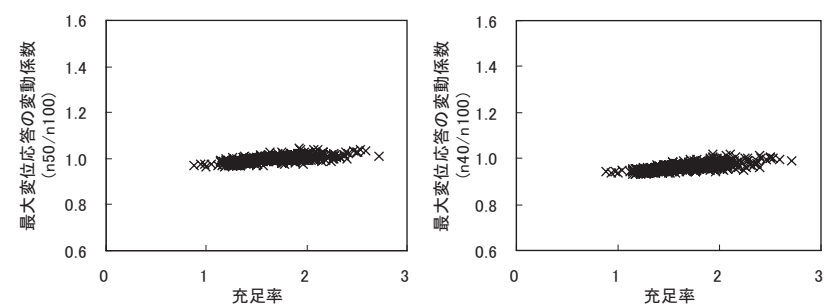

沖積層 A5

50 事例/100 事例

40 事例/100 事例

図 12 地盤増幅特性サンプル数の変動係数比への影響

そこで, 416 ケの建物の平均值比および変動係数比の平均・標準 偏差を図 13，14 に示寸. 地盤増幅特性のサンプル数の影響は, 沖
積層種別, 基盤入力動の大きさにより異なるが, 概ね地盤増幅特性 サンプル数の減少とともに平均值比の平均は 1.0 より外れ平均值比 の標準偏差は増大寸る. また, 変動係数比の平均は, 表層地盤, サ ンプル数の影響を複雑に受け, 変動係数比の標準偏差はサンプル数 の減少とともに増大寸る. しかし, サンプル数を 40 事例, もしく は，50 事例に決定づける強い証拠性は見られない。

以上の結果を踏まえ, 本稿では, 地盤増幅特性のサンプル数をよ り収束する傾向のある 50 事例とすることとした.

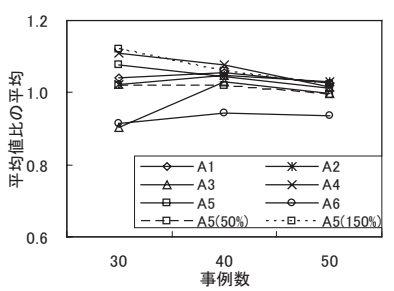

平均

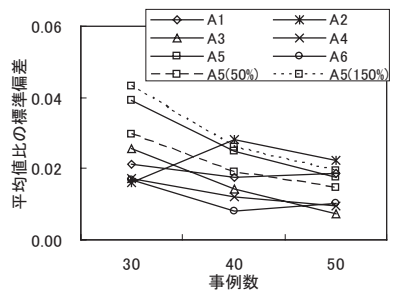

標準偏差
図 13 最大変位応答の平均值比

（計算事例 100 例に対する計算事例 30,40,50 例の場合）

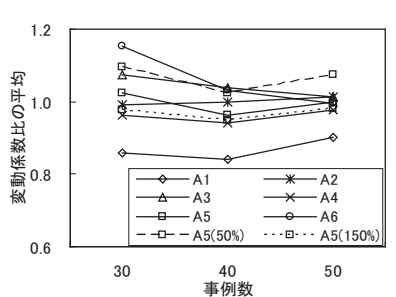

平均

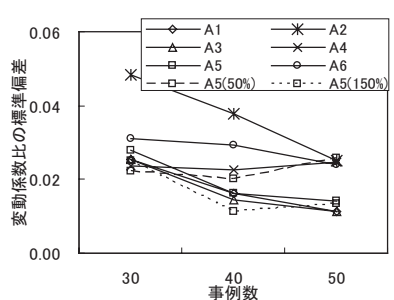

標準偏差
図 14 最大変位応答の変動係数比

（計算事例 100 例に対寸る計算事例 30,40,50 例の場合）

\section{6. 一建物の最大変位応答分布}

本節では, 耐震要素の耐力特性の変動, および, 表層地盤の増幅 特性の変動, 双方を考慮した最大変位応答の変動を検討寸る. 建物 モデルは図 3 とし，既報 ${ }^{1}$ および 4 節の結果より，モンテカルロシ ミュレーションのサンプル数を 20 事例とした. また, 表層地盤は 沖積層 A5 とし, 前節の結果を受けてモンテカルロシミュレーショ ンのサンプル数を 50 事例とした. 以上の建物 20 事例 $\times$ 表層地盤 50 事例 $=1000$ 事例の計算結果を図 15 に示寸. 本計算事例では, 建物 と表層地盤の変動を同時に考慮した場合（“建物と地盤”）の最大 変位応答の分布は, 表層地盤の変動の夕を検討した場合（“表層地 盤のみ”）の最大変位応答の分布に近くなっている. また, 最大変 位応答の最頻值は, 建物と表層地盤の変動を同時に考慮した場合 （“建物と地盤”）と表層地盤の変動のみを検討した場合（“表層 地盤のみ”）で同值となった。

\section{7. まとめ}

本報では，サイトにおける地震動特性のうち“表層地盤における 増幅特性の変動”，および，建物の耐力特性のうち“木造住宅にお ける耐力壁の耐力特性の変動” を考慮し, その最大変位応答一の影 響を考察した。 


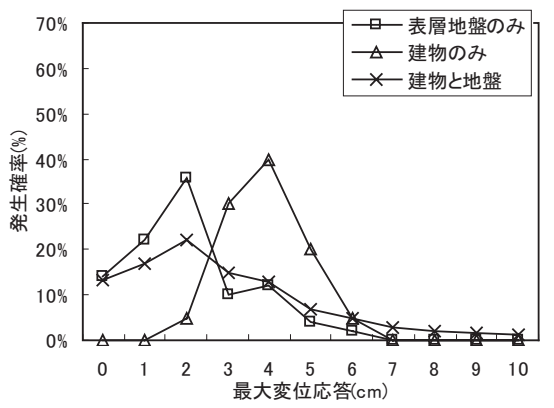

EW 方向

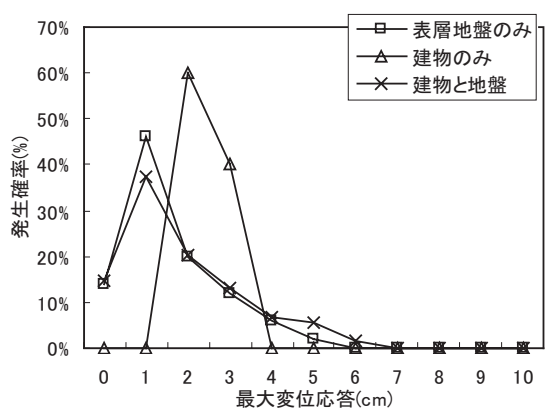

NS 方向

図 15 地盤特性サンプル数 50 事例, 建物サンプル数 20 事例の最 大変位応答の分布（図 3 の建物，沖積層 A5 の場合）

その結果，耐力壁耐力特性の変動の影響は，本報で作成した地震 動においても既報で用いた地震動による最大変位応答の変動と同程 度の值となった。一方, 表層地盤における増幅特性の変動を考慮し た場合には，表層地盤の設定により大きく異なる最大変位応答の変 動が生じた。そこで，本研究の範囲では，モンテカルロシミュレー ションを行う際の表層地盤のサンプル数を 50 事例とし，一建物に 対しモンテカルロシミュレーション (1000 サンプル)を行った結果, 表層地盤増幅特性の変動の影響が推定值の変動の主要因であること, が示された。
以上, 類型化された沖積層の地盤増幅特性の推定誤差を含んだ最 大変位応答分布を検討した. しかし, 本提案手法を実用に供するた めには，具体的な表層地盤特性を用いて更なる検討を要する.

\section{謝辞}

本研究に際し，吉田の公開プログラムを使用した。記して謝意を 表する.

\section{参考文献}

1）山田耕司：耐力の変動を考慮した個別木造軸組建物の被害関数生成法, 日 本建築学会構造系論文集第621号，pp. 97-102，2007.11

2) 山田耕司 : 木造住宅の保有水平耐力分布とその推定法, 日本建築学会技術 報告集 第 18 号, pp. $91-96,2003.12$

3) 山田耕司: 床剛性と雑壁を考慮した木造軸組建物の最大変位応答分布, 日本 建築学会構造系論文集 第586号, pp. 131-137, 2004. 12

4) 河合直人, 岡部実, 渡辺一正 : 在来軸組構法耐力壁の耐震性能 その 2 仮 動的試験，日本建築学会大会学術講演梗概集（九州）, pp.135-136, 1998

5) 山田耕司, 後藤正美: 筋かい耐力壁復元力特性の変動と地震応答の変動, 構 造工学論文集 Vol. 50. B, pp. 327-333，2004. 3

6) 建設省住宅局 : 木造住宅の耐震精密診断と補強方法,1985

7) 山田耕司: 愛知県の在来軸組木造住宅の壁量に関する調査研究, 構造工学 論文集 Vol.46.B, pp.181-188., 2000.3

8) Y. Ohsaki, 0. Sakaguchi : Major types of soil deposits in urban areas in Japan, soil and foundation vol.13, No.2, pp.49-65, 1973

9）耐震地盤調査の計画と管理，酒井運雄，鹿島出版会，p.74

10）長郁夫，趙伯明，香川敬生：増幅スペクトルを評価するための浅部 S 波 速度構造のモデル化一大阪湾岸部一, 日本地震工学会論文集 第5巻, 第1 号, pp. 1-16, 2005

11）吉田望，末富岩雄（1996）：DYNEQ：等価線形法に基づく水平成層地盤の 地震応答解析プログラム, 佐藤工業（株）技術研究所報, pp. 61-70

12）山田耕司: 耐力の変動が木造軸組建物の耐震性能に与える影響, 日本建築 学会構造系論文集 第 599 号, pp. 111-118, 2006.1 